Marzanna Karolczuk

Uniwersytet w Białymstoku

\title{
ROLA REFLEKSII W PRZYGOTOWANIU UCZNIA DO KOMUNIKACJI MIĘDZYKULTUROWEJ NA LEKCJI JĘZYKA ROSYJSKIEGO
}

\author{
The role of reflection in preparing learners for intercultural \\ communication during lessons of Russian
}

\begin{abstract}
This article attempts to identify measures for teaching and learning a foreign language with focus on the reflective and conscious approach. The objective is to develop appropriate attitudes on the part of learners towards Russia and Russians and thus to prepare them for intercultural communication during lessons of Russian as a second foreign language in school. During these lessons work on student attitudes requires the teacher to use multi-faceted techniques and forms of teaching. Among these, worth mentioning is the use of reflective visualization, comparison of cultures, and conscious emphasis of what is valuable and interesting in others. Techniques, which appeal to the emotions of students, and develop their empathy are used in the context of Russian as a second foreign language in school.
\end{abstract}

Keywords: Russian language, second foreign language in school, attitudes, intercultural communication, reflection

Słowa kluczowe: Język rosyjski, drugi język obcy w szkole, postawy, komunikacja międzykulturowa, refleksja

\section{Wstęp}

Stephen R. Covey (2007: 248) podkreśla, że zdolność komunikacji to najważniejsza umiejętność życiowa. Warunkiem skutecznego współdziałania jest 
zrozumienie drugiej osoby. Ocenianie współrozmówcy przed przystąpieniem do dialogu powoduje, że nigdy nie zrozumie się go naprawdę w kontaktach interpersonalnych. Na gruncie edukacji szkolnej również zwraca się uwagę na tę ważną umiejętność. Najważniejszym celem nauki języków obcych, według nowej Podstawy Programowej (PP 2010), jest umiejętność skutecznego porozumiewania się. Należy więc koniecznie uwrażliwić uczących się na inne kultury, języki i narodowości, aby nie oceniali zbyt pochopnie partnera komunikacyjnego reprezentującego inną narodowość oraz jego zachowań werbalnych i niewerbalnych. Uwarunkowania osobowościowe (savoir-être), wiedza (savoir) i umiejętności (savoir-faire) stanowią zasoby jednostki wpływające na jakość działań komunikacyjnych i skuteczność porozumienia z przedstawicielem innej kultury. Jednym z elementów wchodzących w skład czynników indywidualnych związanych z osobą uczącego się są postawy wobec języka obcego (JO) oraz ludzi reprezentujących określony obszar kulturowy.

W niniejszym artykule zidentyfikowano zrozumienie znaczenia postaw uczniów w przygotowaniu do komunikacji międzykulturowej na lekcji języka rosyjskiego. Podjęto również próbę określenia sposobów nauczania i uczenia się, ukierunkowanych na refleksyjne i świadome podejście, kształtujących odpowiednie postawy ucznia wobec Rosji i Rosjan, a tym samym przygotowujących go do komunikacji międzykulturowej na lekcji języka rosyjskiego jako drugiego obcego.

\section{Znaczenie postaw w przygotowaniu do kontaktów międzykulturowych na lekcji JO}

Postawy definiowane są jako „otwartość i zainteresowanie nowymi doświadczeniami, innymi osobami, koncepcjami, narodami, społeczeństwem i kulturami; skłonność do relatywizacji własnego kulturowego punktu widzenia oraz związanego z nim kulturowego systemu wartości; skłonność i umiejętność dystansowania się wobec konwencjonalnych nastawień do różnic kulturowych" (ESOKJ, 2003: 97).

Negatywne emocje związane z wyobrażeniem Rosji, Rosjan i języka rosyjskiego, brak gotowości i chęci poznania, zrozumienia nie tylko zaburzają przyszłe relacje międzykulturowe, ale przede wszystkim utrudniają proces nauczania i uczenia się drugiego języka obcego w warunkach szkolnych. Różnice w przyjętych systemach komunikacyjnych mogą potęgować konflikty na tle odmiennych wartości politycznych, ideologicznych czy społecznych. Często przyczyniają się do tworzenia i utrwalania barier społecznych i podziałów na „my” i „oni”. Dorota Misiejuk (1999: 107) podkreśla, że „najważ- 
niejszą barierą, jaka pojawia się w kontaktach z 'innym', są nasze stereotypy i uprzedzenia. To one bardzo często są podstawą dla decyzji o konkretnych zachowaniach wobec 'Innych'. Decydują o przydzieleniu puli praw i obowiązków wobec świata, danego kraju czy społeczności lokalnej”.

Mimo, że eliminacja i modyfikacja stereotypów i uprzedzeń są wyjątkowo trudne ze względu na ich ogromną trwałość, to „nastawienia można jednak i trzeba kształtować. Zarówno stereotypy, jak też uprzedzenia mogą zatem, poprzez uświadomienie i zastosowanie odpowiednich technik, ulec relatywizacji. Uprzedzenia jako wynik nastawień mogą niekiedy być wyeliminowane bądź zminimalizowane, dzięki czemu zostanie ułatwiona bardziej obiektywna percepcja, a jednocześnie osiągnięta większa otwartość i tolerancja w stosunku do tego, co inne, nieznane" (Zawadzka, 2004: 208; por. Czykwin, 1999: 120).

Przygotowanie do komunikacji międzykulturowej na lekcji języka rosyjskiego powinno również uwzględniać te pozytywne postawy i wyobrażenia uczniów o Rosji i Rosjanach, które zostały nabyte przed rozpoczęciem nauki JO lub ukształtowane w jej trakcie. Są one zazwyczaj związane z wiedzą realioznawczą i kulturoznawczą określonego obszaru językowego. Powinny być wzmacniane jako zjawiska interesujące, ciekawe, które ułatwiają zrozumienie drugiego człowieka i świata oraz motywują jednostkę do głębszego poznawania innej kultury i języka obcego. Jerzy Nikitorowicz (1995: 84) podkreśla, że jednym z celów szczegółowych takiej edukacji jest odbieranie odmienności i „inności” nie jako zagrożenia, ale jako czegoś przyjaznego, co poszerza horyzonty. Reinhold Utri (2008: 107) zaznacza, że „już przed spotkaniem różnych kultur można się uczyć elementów i języka innej kultury, aby 'profilaktycznie' stworzyć pewien poziom znajomości i porozumienia". Elżbieta Czykwin (1999:120) uważa natomiast, iż najlepszym sposobem kreowania właściwych postaw i eliminacji negatywnych jest prewencja.

W budowaniu dobrych postaw chodzi też o to, aby dzięki poznaniu różnic i zrozumieniu przedstawicieli innych kultur, bardziej ubogacać i odnajdywać siebie. „Jak bowiem podkreśla Witkowski, zmaganie się z 'nieprzejrzystością innego' jest sposobem na 'własną nieprzejrzystość'. Lepiej potrafimy zrozumieć siebie, swoją kulturę, własne w niej usytuowanie, jeżeli włożymy wysiłek w zrozumienie kultury innych" (Sobecki, 1999: 92). Dorota Misiejuk (1999: 105) wskazuje, że to właśnie różnice powodują, że dialog jest interesujący, obca kultura cenna dla innych, a głównym zadaniem w procesie edukacji szkolnej ,jest pomoc uczniom zrozumieć tę różnorodność, podłoża konfliktów, uwrażliwić na odmienność nie po to, by je dostrzegać, ale po to, by potrafili twórczo spojrzeć na problemy tego świata. By umieli wziąć udział w pokojowym negocjowaniu konfliktów". 
W kontekście powyższych rozważań warto przytoczyć poglądy Carla Rogersa (1957: 95-103 za Kusio 2011: 76) na temat czynników umożliwiających osobowe interakcje. Wymienia on trzy konieczne i jednocześnie wystarczające warunki dla zaistnienia relacji interpersonalnej. Są to: stosowność, bezwarunkowo pozytywny stosunek oraz pełne empatii zrozumienie.

\section{Diagnoza postaw uczniów wobec Rosji i Rosjan jako warunek przygotowania młodzieży do porozumienia międzykulturowego}

Przeprowadzone w roku szkolnym 2012/13 badanie wśród 90 uczniów dwóch szkół średnich w Białymstoku, którego celem było zdiagnozowanie postaw afektywnych względem Rosji i Rosjan, wykazało, że można je przyporządkować do trzech grup ${ }^{1}$. Jest to obszar negatywnych wyobrażeń o Rosji i Rosjanach, obszar pozytywnych nastawień oraz obszar postaw neutralnych (tabela 1).

\begin{tabular}{|l|l|}
\hline $\begin{array}{l}\text { Rodzaj postaw, } \\
\text { wyobrażeń wobec } \\
\text { Rosji i Rosjan }\end{array}$ & \multicolumn{1}{|c|}{ Przykłady obrazów Rosji i Rosjan w wyobrażeniach uczniów } \\
\hline Negatywne & $\begin{array}{l}\text { Rosja: wydarzenia historyczne (druga wojna światowa, tagry, Katyń, Stalin, } \\
\text { Lenin, komunizm), współczesna sytuacja polityczna (niedemokratyczna, Putin } \\
\text { - dyktator), specyficzny klimat (zimno), duże zróżnicowanie społeczeństwa } \\
\text { pod względem statusu materialnego, kraj słabo rozwinięty; Rosjanie: zacho- } \\
\text { wania obyczajowe (nadużywanie alkoholu), sytuacja ekonomiczno-społeczna } \\
\text { (ludzie bardzo bogaci lub bardzo biedni); cechy: skąpi, wywyższają się, okazu- } \\
\text { ją niechęć dla innych narodów, wulgarni; wygląd: ludzie w czapkach uszat- } \\
\text { kach, babcie w chustkach, ostry makijaż, futra i złote zęby }\end{array}$ \\
\hline Pozytywne & $\begin{array}{l}\text { Rosja: piękne miasta, krajobrazy, zabytki, cerkwie; wspaniała kultura (muzy- } \\
\text { ka, balet, Czajkowski, Anna Karenina); warto zwiedzić; Rosjanie: przyjaźni, } \\
\text { gościnni, zaradni, z poczuciem humoru, dumni ze swojej ojczyzny, wierzący, } \\
\text { dobrzy sportowcy, solidarni wobec swojego narodu, prostota w myśleniu }\end{array}$ \\
\hline Neutralne & $\begin{array}{l}\text { Rosja: brak określonego stanowiska, wyobrażenia, wiedzy } \\
\text { Rosjanie: liczy się człowiek, a nie pochodzenie }\end{array}$ \\
\hline
\end{tabular}

Tabela 1: Postawy uczniów szkół średnich wobec Rosji i Rosjan (opracowanie własne).

Pejoratywne wyobrażenia o Rosji i Rosjanach przyczyniają się do negatywnych postaw, a czasami nawet do wrogiego nastawienia wobec społeczeństwa, kultury i języka rosyjskiego, co przejawia się w wypowiedziach młodzieży

\footnotetext{
${ }^{1}$ Szczegółowe wyniki badania zostały omówione w artykule: M. Karolczuk, 2014. „Postawy uczniów szkół średnich wobec Rosji i Rosjan. Wnioski z badań”. Acta Polono-Ruthenica (w druku). Na potrzeby niniejszego tekstu autorka odnosi się do wyników jakościowych.
} 
(Tam jest patologia; Przede wszystkim Rosja nie podoba mi się ze względów kulturalnych; Religia jest tam bardzo surowa i nie liczq się z ludźmi; Nie cierpię brzmienia tego języka) $)^{2}$. Uczniowie wykazujący przychylne postawy pozytywnie wypowiadają się o Rosji jako kraju, który warto zobaczyć, a Rosjanach jako ludziach, których chętnie poznają (Byłoby to bardzo ciekawe poznać jego [Rosjanina - dop. M.K.] kulturę; Może dzięki temu [dzięki częstszym kontaktom dop. M.K.] moglibyśmy ich lepiej poznać; Cenię ich kulturę, ale nie tq osobistq). Uczniowie, których można zakwalifikować do obszaru neutralnego, wielokrotnie podkreślali, że nie znają Rosjan, ani Rosji na tyle, aby oceniać kraj i społeczeństwo. Ponadto młodzież z trzeciej grupy skupia się w swoich wypowiedziach na człowieku (szefie, sąsiedzie, turyście, partnerze), jego kulturze osobistej, a nie narodowości (Nie miałam możliwości dłuższej rozmowy z Rosjanami, więc nie mogę ich ocenić; Co to za różnica kim będzie mój sq̨siad?; Jeśli będzie dobrym przełożonym, to narodowość nie ma znaczenia).

Nie ulega wątpliwości, że aby umiejętnie kształtować postawy, nastawienia, wyobrażenia ucznia nauczyciel powinien je najpierw zidentyfikować. Pozytywne asocjacje warto zatem wzmacniać, rozwijać, negatywne zaś powinny być punktem wyjścia do przemyśleń uczniów nad dotychczasowym postrzeganiem innej kultury, do rozwijania umiejętności uświadomienia i zrozumienia zjawisk kulturowych.

\section{Refleksja jako świadome odzwierciedlenie obiektywnej rzeczywistości}

Wydaje się, że aby zrozumieć należy „zatrzymać się”, zatrzymać szybko płynące myśli, zastanowić się, przeanalizować jakieś zjawisko. Refleksja jest niezbędna, aby pogłębić pozytywne nastawienie lub zweryfikować dotychczasową opinię o społeczności, której języka młodzież uczy się, a w konsekwencji przygotować do dobrych kontaktów z osobami z różnych obszarów kulturowych. Chodzi o to, aby uczeń uświadomił sobie, że jego widzenie świata jest często subiektywne; poznawanie, otwieranie się na nowe doświadczenia jest wartością wzbogacającą jego samego, a nieuzasadnione ocenianie negatywnie stygmatyzuje kontakty międzykulturowe. Refleksja ściśle wiąże się z pojęciem świadomości, które definiowane jest „jako zdolność umysłu ludzkiego do zdawania sobie sprawy (m.in. do słownego opisania) z własnych przeżyć psychicznych, a więc do odzwierciedlania obiektywnej rzeczywistości" (Szulc, 1997: 213). Wanda Woronowicz (2006: 28) definiuje refleksję jako stan „głębokiego namysłu przed działaniem lub wydaniem oceny czegokolwiek. Refleksyjny jest zatem taki człowiek, który nie

\footnotetext{
${ }^{2}$ Kursywą zapisano oryginalne odpowiedzi ankietowanych.
} 
podejmuje czynności, ani nie wygłasza pochopnych osądów, zanim problemu dokładnie nie przemyśli (...). Istotny jest tu zatem problem samoświadomości, zwrócenia myśli ku sobie samej".

Budowanie harmonijnych stosunków między osobami reprezentującymi różne kultury, przygotowanie do dialogicznych interakcji można osiągnąć drogą krytycznej refleksji, której zasadniczym punktem jest świadomość w nabywaniu wiedzy w obszarze podobieństw i różnic między kulturami, rozpoznawanie własnej tożsamości kulturowej, analizowanie procesów komunikacyjnych (Misiejuk, 1999: 106). Przygotowanie do kontaktów z przedstawicielami innej kultury wymaga rozwijania u uczniów umiejętności samodzielnej refleksji nad posiadaną wiedzą o innej narodowości, dokonywania systematycznej weryfikacji posiadanej wiedzy i nastawień pod kierunkiem nauczyciela. Świadoma analiza różnych obszarów innej kultury może spowodować, że "nauka języków obcych będzie przeciwdziałała istniejącym negatywnym stereotypom i uprzedzeniom” (Zawadzka, 2004: 215). Zuzanna Bogumił (2009: 174), która odbyła podróż do Rosji i opowiedziała o tym doświadczeniu poprzez zrobione przez siebie fotografie, akcentuje znaczenie świadomej obserwacji otaczającego ją świata i snuje istotny dla naszych rozważań wywód: „Kiedy jeszcze raz przyglądam się wybranym przez siebie zdjęciom, ciekawy wydaje mi się fakt, że te, które uznałam za stereotypowy sposób patrzenia na rzeczywistość, to gównie fotografie zrobione wówczas, gdy nie koncentrowałam się na badanym przez siebie zjawisku, a po prostu 'pstrykałam zdjęcia'. Z kolei widoki, które, moim zdaniem, odkrywają głębsze treści, to te wykonane w sposób świadomy".

Praca na lekcji języka rosyjskiego nad postawami uczniów wobec przedstawicieli innych kultur, pobudzanie ciekawości, rozwijanie otwartości na nowe doświadczenia oraz zdolności refleksyjnej obserwacji własnej kultury wymaga uwzględnienia przez nauczyciela wieloaspektowego wykorzystania metod i form nauczania. Należy też zaznaczyć, że biorąc pod uwagę kontekst szkolny, refleksja podejmowana przez młodzież w trakcie lekcji, następuje po zdiagnozowaniu postaw uczniów, a tym samym uświadomieniu przez nich nastawień wobec Rosji i Rosjan. Obejmuje ona świadomą analizę treści werbalnych oraz wizualnych, pod kierunkiem nauczyciela oraz autoanalizę wypowiadanych przez uczniów sądów, opinii, przekonań. Zaproponowane niżej sposoby pracy na lekcji uzupełniają się ${ }^{3}$.

3 Przedstawiona koncepcja ma charakter ramowy. Konkretne zadania omówiono w artykule: M. Karolczuk, 2014. „Sposoby kształtowania postaw uczniów wobec Rosji i Rosjan na lekcji języka rosyjskiego jako drugiego obcego" (w:) W dialogu języków i kultur, Warszawa (w druku). 
- Stosowanie refleksyjnej wizualizacji na lekcji języka rosyjskiego Wykorzystanie szeroko rozumianej wizualizacji na lekcji języka rosyjskiego jest szczególnie uzasadnione. Umożliwia, wydaje się, że najszybciej, pokazanie zjawisk niedostępnych bezpośredniej obserwacji. Ułatwia korygowanie negatywnych wyobrażeń uczniów lub pogłębienie zainteresowania tematami kulturoznawczymi, realioznawczymi, a także zaciekawienie nowymi. Może to być wykorzystanie fragmentów programów telewizyjnych, Internetu, fotografii, obrazów lub albumów fotograficznych. Tego typu materiały dydaktyczne uczeń może uznać za bardziej wiarygodne niż teksty i zdjęcia z podręczników, ponieważ są aktualne. Wincenty Okoń (2003: 289) zauważa, że takie środki dydaktyczne mogą być „przekaźnikiem tak cennych wartości, tak wspaniałych wzorów postępowania, że jako czynnik pobudzający ludzi do wzruszeń oraz kształtujący ich motywacje i postawy staje się czymś nie do zastąpienia". Takie poznanie może implikować głębsze zrozumienie rzeczywistości, bardziej obiektywne spojrzenie na Rosję i jej mieszkańców.

Z perspektywy kształtowania postaw i nastawień szczególną wartość poznawczą mają wiadomości, ale także programy "na żywo", przyrodnicze, rozrywkowe, lub podejmujące problemy społeczne. Osoba ucząca się poznaje realia Rosji, wycinki życia codziennego jej mieszkańców, ich wygląd, problemy, ale również radości, sposób zachowania werbalnego i niewerbalnego w tych sytuacjach. Programy te inspirują do przemyśleń nad dotychczasowym postrzeganiem danej narodowości, często obalają stereotypy, mity o danej społeczności, zmieniają nastawienie do niej. Duże znaczenie poznawcze mają również filmy fabularne i dokumentalne. Obcojęzyczne filmy pokazują postrzeganie innych kultur przez twórców tych filmów lub ich bohaterów (na przykład Polaków, Amerykanów przez Rosjan), sposób rozumienia innych narodowości, co może być przyczynkiem do refleksji i dyskusji podejmowanej przez uczniów.

- Refleksyjne porównywanie kultur w celu uświadomienia przez uczniów różnic Przede wszystkim akcentuje się podejście porównawcze w zakresie kultury własnej ucznia oraz kultury dla niego Innej, nieznanej lub w danym momencie niechcianej. Celem takiego nauczania jest „pokazanie uczniowi, że własny styl życia i postępowania nie jest 'naturalny' (czyli jedyny możliwy), ale 'kulturalny' (czyli opanowany podświadomie w efekcie przebywania w określonym otoczeniu). W podejściu porównawczym istotne jest wskazanie dynamiki zachowań kulturowych, możliwości wprowadzania zmian, familiaryzowania tego, co obce i rozwijanie umiejętności obserwowania z dystansem tego, co własne, także pod kątem ewentualnego wprowadzenia zmian“ (Aleksandrowicz-Pędich, 2005: 36). Uświadomienie różnic między kulturą ucznia a kulturą przez niego odkrywaną, czasem Obcą lub Inną, wpływa na wnikliwe poznanie i zrozumienie tej drugiej, ale również na umacnianie toż- 
samości kulturowej ucznia. Dbanie o tożsamość kulturową uczącego się jest niezbędnym ogniwem w procesie nauczania i uczenia się JO, ponieważ „uznanie tożsamości innych jest jednak domeną osób posiadających silne poczucie swojej własnej tożsamości społecznej, która podczas kontaktu z innością zostaje dodatkowo wzmocniona i wzbogacona" (Mikułka, 2013: 61).

- Refleksyjne podkreślanie podobieństw i podejmowanie tematów trudnych Jednym ze sposobów modyfikacji uprzedzeń i stereotypów postulowanych przez B. Weigla i W. Łukaszewskiego (1992, por. Rodczenkowa, 2009: 66) jest akcentowanie podobieństw, które polega na ukierunkowaniu percepcji jednostki na to, co nas łączy. Badania wskazują, że takie podejście zwiększa sympatię do drugiej osoby - podobnej do JA, zmniejsza prawdopodobieństwo zachowań agresywnych. Podobny pogląd wyraża Agata Bachórz (2009: 127): „kultura obca staje się w przyjemny sposób 'mniej obca', jeśli mniej obcy okazują się jej przedstawiciele (oraz - symetrycznie - jeżeli my jesteśmy przez nich traktowani jako swoi)".

Nie należy unikać tematów trudnych, wybielać historii, ale wręcz przeciwnie uwzględniać kontekst historyczny, doświadczenie sąsiedztwa Polski i Rosji, z istniejącym bagażem mitów, stereotypów i spetryfikowanych w kulturze wzajemnych obrazów. Podejście takie powoduje, że nauczyciel staje się bardziej wiarygodny w oczach ucznia, a proces nauczania i uczenia się JO autentyczny, szczery, niezakłamany. Lucyna Aleksandrowicz-Pędich (2005: 37) konstatuje, że podstawową zasadą takiego kształcenia powinien być „szacunek dla tożsamości kształconego i odstępowanie od prób 'przerobienia' go na inny model kulturowy".

- Świadome akcentowanie tego, co wartościowe i interesujqce u innych Władysław Figarski (2003: 98) zaznacza, że „rozbudzenie zainteresowań życiem, obyczajami, kulturą, osiągnięciami innych narodów prowadzi do zachowań wyzwalających chęć poznania także języków obcych i uzyskiwania w tej dziedzinie znacznych sukcesów". Danuta Markowska (1994: 325-334), analizując społeczności pogranicza, podkreśla, że inne, obce staje się po prostu potrzebne wówczas, gdy postrzegane jest jako interesujące, fascynujące, potrzebne dla zrozumienia świata, motywów działań ludzi w bliższym i dalszym otoczeniu.

Podkreślanie na lekcji języka rosyjskiego tego, co wartościowe i interesujące $w$ innej kulturze przyczynia się nie tylko do zaciekawienia, ale też do relatywizacji własnego kulturowego punktu widzenia, ponieważ „dostrzeganie tego, co wartościowe u innych, wiąże się ze zwiększonym wysiłkiem pozytywnej waloryzacji własnej kultury" (Sobecki, 1999: 94). Umiejętna praca na lekcji JO ze stereotypami odnoszącymi się do innych narodowości może pozytywnie oddziaływać na autostereotyp polskich uczniów, który „często jest niebez- 
Rola refleksji w przygotowaniu ucznia do komunikacji międzykulturowej...

piecznie niski. Samoocena Polaków to zwykle pasmo wad narodowych, a niska samoocena nie wpływa na udane kontakty międzykulturowe. Uprzedzenie, połączone z poczuciem niższości, z góry upośledza jakość kontaktów pomiędzy przedstawicielami różnych kultur" (Aleksandrowicz-Pędich, 2005: 27).

- Odwoływanie się do emocji uczniów, rozwijanie ich empatii Marzena Żylińska (2003: 52) zwraca uwagę, że nauczanie JO wymaga uwzględnienia potrzeb emocjonalnych ucznia, zwłaszcza rozwijania empatii oraz zdolności „akceptowania odmiennych postaw i patrzenia na świat z różnych punktów widzenia". Należy podkreślić, że rozwijanie empatii jest szczególnie trudne, ponieważ, jak dowodzi Stephen R. Covey (2007: 251), jednostka zwykle stara się, aby to ją zrozumiano, na świat patrzy przez pryzmat samego siebie, wypełniona jest własną autobiografią, a kontakt z drugą osobą przybiera często postać monologu, a nie rozmowy. Empatyczny dialog jest trudny między osobami reprezentującymi tę samą kulturę i wydaje się być jeszcze trudniejszy pomiędzy jednostkami reprezentującymi różne kultury. Można by nawet zastosować termin empatia międzykulturowa, rozumiana jako przyjęcie punktu widzenia osoby innej narodowości, patrzenie na nią przez jej pryzmat, rozumienie, co czuje rozmówca, widzenie świata, w taki sposób, w jaki widzi ta osoba, ze świadomością przynależności rozmówcy do innego kręgu kulturowego. Mirosław Sobecki (1999: 92-93), zauważa, że empatia polega „na odnalezieniu rezonansu z tym co inne. Owo współbrzmienie ma mieć charakter nie tyle emocjonalny, co intelektualny i powinno być budowane na solidnej wiedzy dotyczącej różnych dymensji odmienności". Należy jednak pamiętać, że uczenie się empatii, zrozumienia jest procesem długotrwałym, trwającym niekiedy całe życie (por. Mikułka, 2012: 108).

- Aktywność ucznia w interpretacji postrzeganej przez niego rzeczywistości Tylko inicjatywa, interakcja i aktywny udział w poznaniu, zrozumieniu i działaniu buduje postawę dialogu i mądrego otwarcia na inne kultury i języki (Sobecki, 1999: 92). Samo przebywanie w zróżnicowanym kulturowo środowisku nie przyczynia się do empatycznej percepcji problemów innych i nie czyni jednostki bardziej otwartą (Górniewicz, 2000: 344). Bierne przyjęcie przez ucznia informacji - niezgodnej, na przykład ze stereotypem czy jego wyobrażeniem o społeczności, której języka się uczy - nie spowoduje modyfikacji postaw i nastawień. Ze względu na silne powiązanie stereotypu z emocjami należy zadbać o to, aby uczniowie uświadomili sobie emocje związane z postawą wobec innej kultury i jej przedstawiciela. Dorota Misiejuk (1999: 107) zaznacza, że interpretacja uprzedzeń i stereotypów wpływa na postawy jednostki, a nie intelektualne dyskusje czy przywoływanie autorytetów, „zachowaniem bowiem kieruje percepcja rzeczywistości. Forma warsztatów przy modyfikacji 
stereotypów i uprzedzeń pozwala zrealizować założenia podejścia psychodynamicznego, gdzie każde zachowanie jest znaczące".

Na kształtowanie postaw, nastawień uczniów, jak również na motywowanie do autonomicznej pracy ma wpływ nie tyle liczba informacji, co odpowiednia prezentacja i interpretacja. Stanowczo podkreśla się znaczenie indywidualnego wysiłku ucznia w zdobyciu wiedzy o innej kulturze (Aleksandrowicz-Pędich, 2005: 36). Chodzi o to, aby w pełni zaangażować ucznia w poznanie tego, co jest niezrozumiałe, nacechowane negatywnie czy odbierane subiektywnie, ale też zaangażowanie w poznanie tego, czym się interesuje.

- Uwzględnienie koncepcji nauczania języka rosyjskiego jako drugiego obcego w szkole

Ważną regułą w procesie nauczania drugiego języka obcego jest stosowanie porównań w ramach trzech języków: ojczystego, pierwszego i drugiego języka obcego (Chłopek, 2009; Jakowlewa, 2001). Chodzi tu o poznanie różnych płaszczyzn kulturowych poprzez porównania (elementów realioznawczych, kulturoznawczych, socjokulturowych, stylów komunikacyjnych). Porównania w ramach trzech kultur są pomocne w kształtowaniu odpowiednich postaw uczniów, uświadamiają uczącym się różne wymiary kulturowe, pozwalają zdystansować się do kultury docelowej, uczą wnikliwej obserwacji z punktu widzenia przedstawiciela zupełnie innej kultury; rozwijają otwartość, kształtują wrażliwość, empatię, umiejętność oceniania bez negatywnego wartościowania. Uczeń uzmysławia sobie, że język rosyjski może być rzeczywistym narzędziem, przy pomocy którego można mówić o różnorodnych problemach obejmujących nie tylko polski lub rosyjski obszar językowy i kulturowy. Poza tym, takie podejście umożliwia wykorzystanie wiedzy i umiejętności już posiadanych przez ucznia, nabytych również $\mathrm{w}$ ramach nauki pierwszego języka obcego, co uświadamia zasadność i celowość podjętego wcześniej wysiłku i dodatkowo motywuje do dalszej pracy. Koncepcja nauczania języka rosyjskiego jako drugiego obcego $\mathrm{w}$ szkole nawiązuje do podejścia pluralistycznego, którego główną ideą jest zapewnienie kontaktu z różnymi językami i kulturami, co ma „decydujące znaczenie dla rozwoju pozytywnych przekonań i postaw wobec różnorodności językowej i kulturowej, a także wobec nauki języków" (Candelier i Schröder-Sura, 2013: 6).

\section{Podsumowanie}

W niniejszym artykule podjęto próbę przedstawienia sposobów pracy na lekcji języka rosyjskiego, zorientowanych na refleksyjne i świadome podejście. Ich celem jest kształtowanie odpowiednich postaw ucznia wobec Rosji 
i Rosjan, a tym samym przygotowanie go do komunikacji międzykulturowej oraz dialogu w warunkach pozaszkolnych. Zaproponowana ramowa koncepcja uwzględnia zidentyfikowane postawy uczniów, ponieważ determinują one skuteczność werbalnego porozumienia. Jak słusznie podkreśla Dorota Misiejuk (1999: 105) „nie należy jednak zapominać, że procesów porozumienia się i dialogu nie można dowolnie przyspieszać. Nie służy temu też pomijanie tego, co dzieli różne kultury w imię niekreowania konfliktu i zacierania różnic poprzez wyodrębnianie cech wspólnych". Wymowna jest konstatacja Magdaleny Kucharewicz (2009: 183):

Zgadzam się w pełni ze słowami Ryszarda Kapuścińskiego (2007: 10), który w jednej ze swoich notatek napisał 'Rosja była, jest i będzie. Była, jest i będzie wielka - w dobrym i złym'. A ja ośmielam się dodać, że tylko od nas zależy, czy będziemy potrafili dostrzec jej oba oblicza. Czy za pancerzem stereotypów zamkniemy się na jej lepszą stronę? A może brakuje nam odwagi, by spojrzeć w jej kierunku wychylając się zza lustra antagonizmów, w którym się na co dzień przeglądamy?

\section{BIBLIOGRAFIA}

Aleksandrowicz-Pędich, L. 2005. Międzykulturowość na lekcjach języków obcych. Białystok: Wydawnictwo Uniwersytetu w Białymstoku.

Bachórz, A. 2009. „Podróżowanie jako obszar negocjacji pomiędzy swojskością a obcością. Przypadek polskich wyjazdów do Rosji" (w:) Wizje kultury własnej, obcej i wspólnej w sytuacji kontaktu. (red. M. Kostaszuk-Romanowska, A. Wieczorkiewicz). Białystok: Galeria im. Sleńdzińskich: 124-136.

Bogumił, Z. 2009. „Wyspy Sołowieckie w obiektywie fotograficznym antropologa” (w:) Wizje kultury własnej, obcej i wspólnej w sytuacji kontaktu. (red. M. Kostaszuk-Romanowska, A. Wieczorkiewicz). Białystok: Galeria im. Sleńdzińskich. 162-174.

Candelier, M., Schröder-Sura, A. 2013. „Wspieranie rozwoju kompetencji różnojęzycznych i międzykulturowych w klasie szkolnej”. Języki Obce w Szkole 2: 4-11.

Chłopek, Z. 2009. „Kształcenie nauczycieli języków trzecich lub kolejnych” (w:) Nauczyciel języków obcych dziś i jutro. (red. M. Pawlak, A. Mystkowska-Wiertelak, A. Pietrzykowska). Poznań-Kalisz: Wydział Pedagogiczno-Artystyczny UAM w Poznaniu: 167-177.

Covey, S. R. 2007. 7 nawyków skutecznego działania. Poznań: Dom Wydawniczy REBIS.

Czykwin, E. 1999. „Próba modyfikacji stereotypów i uprzedzeń narodowych w warunkach szkoły" (w:) Edukacja międzykulturowa w wymiarze instytucjonalnym. (red. J. Nikitorowicz, M. Sobecki). Białystok: Trans Humana: 120-131.

ESOKJ: Europejski System Opisu Kształcenia Językowego: uczenie się, nauczanie, ocenianie, 2003. Warszawa: Wydawnictwo CODN.

Figarski, W. 2003. Proces glottodydaktyczny w szkole. Warszawa: Wydawnictwo UW. 
Górniewicz, J. 2000. „Problem tolerancji w kulturze pogranicza” (w:) O nowy humanizm w edukacji. (red. J. Gajda). Kraków: Impuls.

Jakowlewa: Яковлева, Л. Н. 2001. „Межкультурная коммуникация как основа обучения второму иностранному языку". Иностранные языки в школе 6: 4-7.

Kucharewicz, M. 2009. „Moja Rosja - Diwiejewo” (w:) Wizje kultury własnej, obcej i wspólnej w sytuacji kontaktu. (red. M. Kostaszuk-Romanowska, A. Wieczorkiewicz). Białystok: Galeria im. Sleńdzińskich: 175-183.

Kusio, U. 2011. Dialog w komunikacji międzykulturowej. Ideały a rzeczywistość. Lublin: Wydawnictwo Uniwersytetu Marii Curie Skłodowskiej.

Markowska, D. 1994. „Kategoria 'swój-obcy' - omówienie” (w:) Oblicza peryferyjności. (red. T. Popławski). Białystok: Wydawnictwo Filii UW: 325-334.

Mihułka, K. 2012. „Sposoby rozwijania kompetencji interkulturowej na lekcji języka obcego". Języki Obce w Szkole 2: 106-117.

Mihułka, K. 2013. „Spotkania interkulturowe z perspektywy uczenia się i nauczania języka obcego" . Języki Obce w Szkole 2: 61-69.

Misiejuk, D. 1999. „Ja wobec Innego - program edukacyjny dla dzieci żyjących w przestrzeni wielokulturowej" (w:) Edukacja międzykulturowa w wymiarze instytucjonalnym.(red. J. Nikitorowicz, M. Sobecki). Białystok: Trans Humana: 104-111.

Nikitorowicz, J. 1995. Edukacja międzykulturowa. Białystok: Trans Humana.

Okoń, W. 2003. Wprowadzenie do dydaktyki ogólnej. Warszawa: Wydawnictwo Akademickie „Żak”.

PP: Podstawa programowa z komentarzami. Tom 3. Języki obce w szkole podstawowej, gimnazjum i liceum, 2010. http://www.men.gov.pl/images/stories/pdf/Reforma/ men_tom_3.pdf DW 17.02.2013.

Rodczenkowa: Родченкова, Е.С. 2009. „Формирование гуманистических ценностей у подростков на уроках немецкого языка". Иностранные языки в школе 6: 65-70.

Rogers, C. 1957. „The necessary and sufficient conditions for therapeutic personality change". Journal of Consulting Psychology 2: 95-103.

Sobecki, M. 1999. „Kształtowanie postaw wobec odmienności jako nowe zadanie wychowania" (w:) Edukacja międzykulturowa w wymiarze instytucjonalnym. (red. J. Nikitorowicz, M. Sobecki). Białystok: Trans Humana: 91-98.

Szulc, A. 1997. Słownik dydaktyki języków obcych. Warszawa: PWN.

Utri, R. 2008. „Filmy jako możliwość interkulturowego uczenia się - na podstawie amerykańskiego filmu Moje wielkie greckie wesele i austriackiego filmu I love Vienna". Przeglad Glottodydaktyczny 25: 107-117.

Weigl, B., Łukaszewski, W. 1992. Uprzedzenia i stereotypy etniczne u dzieci. Przeciwdziałanie i modyfikacja. Opole: Uniwersytet Opolski.

Woronowicz, W. 2006. Refleksja, sumienie, edukacja. Słupsk: Wydawnictwo Pomorskiej Akademii Pedagogicznej.

Zawadzka, E. 2004. Nauczyciele języków obcych w dobie przemian. Kraków: Impuls.

Żylińska, M. 2003. „Podejście interkulturowe, czyli o konieczności zmian w nauczaniu języków obcych". Języki Obce w Szkole 6: 49-62. 